Article

\title{
Implementation of the No Poverty Sustainable Development Goal (SDG) in Visegrad Group (V4)
}

\author{
Elżbieta Sobczak ${ }^{1}\left(\mathbb{D}\right.$, Bartosz Bartniczak $^{2}$ (D) and Andrzej Raszkowski ${ }^{1, *(D)}$ \\ 1 Department of Regional Economy, Wroclaw University of Economics and Business, Nowowiejska 3, \\ 58-500 Jelenia Góra, Poland; elzbieta.sobczak@ue.wroc.pl \\ 2 Department of Quality and Environmental Management, Wroclaw University of Economics and Business, \\ Nowowiejska 3, 58-500 Jelenia Góra, Poland; bartosz.bartniczak@ue.wroc.pl \\ * Correspondence: andrzej.raszkowski@ue.wroc.pl; Tel.: +48-606-262-335
}

check for

updates

Citation: Sobczak, E.; Bartniczak, B.; Raszkowski, A. Implementation of the No Poverty Sustainable Development Goal (SDG) in Visegrad Group (V4). Sustainability 2021, 13, 1030. https://doi.org/10.3390/ su13031030

Received: 25 December 2020 Accepted: 18 January 2021 Published: 20 January 2021

Publisher's Note: MDPI stays neutral with regard to jurisdictional claims in published maps and institutional affiliations.

Copyright: (c) 2021 by the authors. Licensee MDPI, Basel, Switzerland. This article is an open access article distributed under the terms and conditions of the Creative Commons Attribution (CC BY) license (https:/ / creativecommons.org/licenses/by/ $4.0 /)$.

\begin{abstract}
This presented study discusses problems related to the implementation of the Sustainable Development Goal 1: No Poverty, aimed at eliminating poverty, based on the example of the Visegrad Group (V4) countries. The introduction addresses the general characteristics of the V4 and attempts to define the concept of sustainable development, with particular emphasis on its complex nature and importance for future generations. The purpose of the research was to assess the diversity within the Visegrad Group countries in the years 2005-2018 in terms of poverty and sustainable development level in the No Poverty area and also to identify the impact of the socioeconomic development level in the studied countries on sustainable development in the No Poverty area. Taking into account the analysis of poverty indicators in the Visegrad Group countries, the best results were recorded for Czechia. The second part of the conducted analyzed allowed us to conclude that Czechia definitely presents the highest level of sustainable development, followed by Slovakia. The highest average dynamics of changes occur in Poland and Hungary, which result in the gradual elimination of the existing disproportions. Among other research results, it is worth highlighting that the V4 countries show significant, however, decreasing differences regarding the indicators describing poverty in relation to sustainable development.
\end{abstract}

Keywords: Visegrad; poverty; SDG; European Union; sustainability; sustainable development; multidimensional statistical analysis; Czechia; Hungary; Poland; Slovakia

\section{Introduction}

The Visegrad Group (V4), also referred to as the Visegrad Triangle (until 1993) or the Visegrad Quadrangle, is an informal term that has been used since 1991 in relation to three Central European countries: Czechoslovakia, Poland and Hungary-the Visegrad Triangle. Since 1 January 1993, as a result of the break-up of Czechoslovakia, the Czech Republic (in short Czechia) and Slovakia became the members of the Visegrad Triangle and the Triangle changed its name to the Visegrad Group. The group aims at encouraging optimal cooperation with all countries, primarily the neighboring ones, and its ultimate goal is to develop democracy in all parts of Europe [1,2]. The intention of the V4 Group is to contribute towards developing European security based on effective, complementary and mutually supportive cooperation and coordination within the framework of the existing European and transatlantic institutions. In order to preserve and promote cultural community, the cooperation within the Visegrad Group is focused on strengthening the transfer of values in the field of culture, education, science and information exchange. The general information about the V4 members is presented in the Table 1 below. 
Table 1. Basic characteristics of the Visegrad Group (V4) members (2019).

\begin{tabular}{cccc}
\hline Country & Population $(\mathbf{m l n})$ & GDP Per Capita at Market Prices (EUR) & Area Thousand km $^{2}$ \\
\hline Czechia & 10.6 & 20.610 & 78.866 \\
Hungary & 9.7 & 14.720 & 93.030 \\
Poland & 37.9 & 13.730 & 312.685 \\
Slovakia & 5.4 & 17.270 & 49.035 \\
\hline
\end{tabular}

Source: authors' compilation based on Eurostat [3].

The area of V4 spreads over 533.6 thousand $\mathrm{km}^{2}$. It is inhabited by over 63.8 million people. Poland is the largest country, covering $58.6 \%$ of the total area. Poland is also the largest country in terms of population. Its population accounts for approx. $59.5 \%$ of the entire V4 population. The highest GDP per capita was recorded in Czechia, whereas the lowest was recorded in Poland, i.e., over 33\% lower than in Czechia. However, the variation level within the V4 Group was relatively small.

For the purposes of introducing the research problem, sustainable development can be defined as the process of transformations, which ensures meeting the needs of the present generation without compromising the development opportunities of future generations, including integrated actions in the area of economic, social and environmental development. The overall perception of sustainable development, taking into account all its dimensions, is crucial in this respect. The cited definition adopts that the economic and civilization development of the present generation should not be carried out at the expense of nonrenewable resources' depletion and environmental destruction, for the benefit of future generations, who will also have the right to pursue their development [4-20]. The presented understanding of sustainable development was popularized as a result of publishing the World Commission on Environment and Development report, entitled Our Common Future. Further development of this idea was continued at the Earth Summit 1992, following which the document Agenda 21 was developed. The Millennium Declaration of the United Nations, in which the Millennium Development Goals were defined, was another milestone in the activities for sustainable development. The implementation of these goals aimed at allowing an effective approach towards the challenges of the 21st century by 2015. The provisions of the 1992 summit were renewed in 2002 in Johannesburg, and next at the summit in Rio de Janeiro in 2012, referred to as Rio+20. At this summit, The Future We Want declaration was adopted, in which the participants expressed their willingness to promote the idea of a sustainable future on the economic, social and environmental level. The Millennium Development Goals were replaced in 2015 by the Sustainable Development Goals (SDGs) included in the Transforming Our World 2030 Development Agenda. The 2030 Agenda for Sustainable Development represents a development plan for the world, with the goal to eliminate poverty by 2030, to allow dignified life for all and to ensure peace. Sustainable development, or rather striving for its fullest achievement, is undoubtedly one of the most important challenges of the modern world [21-26].

From a different perspective, equally important for the Visegrad Group, the principle of sustainable development, referring to the projects co-financed from European funds, means that social and economic development must not remain in conflict with the interests of environmental protection and spatial order. The planned activities must take into account the needs of future generations, and must not violate the natural and spatial balance. All activities will be implemented considering the needs of preserving biodiversity, taking a sustainable approach to the use of natural resources, to the restoration and consolidation of spatial order, as well as the protection requirements of the naturally valuable areas, including their integrity and coherence.

The aforementioned Sustainable Development Goals (SDG) are monitored using indicators grouped into 17 areas corresponding to the following goals: Goal 1: No Poverty, Goal 2: Zero Hunger, Goal 3: Good Health and Well-being, Goal 4: Quality Education, Goal 5: Gender Equality, Goal 6: Clean Water and Sanitation, Goal 7: Affordable and Clean Energy, Goal 8: Decent Work and Economic Growth, Goal 9: Industry, Innovation and 
Infrastructure, Goal 10: Reduced Inequality, Goal 11: Sustainable Cities and Communities, Goal 12: Responsible Consumption and Production, Goal 13: Climate Action, Goal 14: Life Below Water, Goal 15: Life on Land, Goal 16: Peace, Justice and Strong Institutions and Goal 17: Partnerships to Achieve the Goal. It can be assumed that the implementation of the Sustainable Development Goals is a natural process for the Visegrad Group countries and for the subsequent stage in creating a better place to live for future generations. Focusing the carried out activities in a coordinated, monitored manner, based on principles, guidelines and indicators remains, beyond any doubt, the advantage of this process [27-31].

The purpose of the research discussed in the study was to assess spatial diversity of the Visegrad Group countries in dynamic terms, taking into account the level of poverty and sustainable development in the No Poverty area (poverty elimination) and to identify the impact of the socioeconomic development level of the analyzed countries on sustainable development in the No Poverty area. Gross domestic product per capita was used in the conducted empirical research to assess the level of socioeconomic development, whereas the level of sustainable development in the No Poverty area was determined based on taxonomic measures of development, designed using linear ordering methods.

The analysis was based on the indicators used to monitor Sustainable Development Goal (SDG) No. 1: No Poverty. The research attempted to provide answers to the following research questions:

1. Were the Visegrad Group countries, in the years 2005-2018, significantly differentiated in terms of poverty indicators adopted by the European Union?

2. Did the spatial variation of poverty in the analyzed countries shows a tendency to change over time and what was the direction of these changes?

3. Did the level of sustainable development in the No Poverty area in the Visegrad Group countries increase in the analyzed period and were the dynamics of its changes spatially diversified?

4. Is there a correlation between the level of sustainable development in the No Poverty area and the level of socioeconomic development of the individual Visegrad Group countries?

\section{Materials and Methods}

The presented study provides the analysis of indicators characterizing the area of SDG 1: No Poverty. This area is characterized by 10 following indicators: people at risk of poverty or social exclusion (1.1), people at risk of income poverty after social transfers (1.2), severely materially deprived people (1.3), people living in households with very low work intensity (1.4), in work at-risk-of-poverty rate (1.5), population living in a dwelling with a leaking roof, damp walls, floors or foundation or rot in window frames of floor by poverty status (1.6), self-reported unmet need for medical examination and care by sex (1.7), population having neither a bath, nor a shower, nor indoor flushing toilet in their household by poverty status (1.8), population unable to keep home adequately warm by poverty status (1.9) and overcrowding rate by poverty status (1.10). For all of them, the data covering the years 2005-2018 are available. The indicator self-reported unmet need for medical examination and care by sex is an exception, as the respective data are available since 2008. The definitions of each of them are presented in Table 2. 
Table 2. Sustainable development indicators from the No Poverty area selected for the analysis.

No. Indicator Definition

\section{$\mathrm{X}_{1} \quad$ People at risk of poverty or social exclusion (\%)}

$\mathrm{X}_{2} \quad$ People at risk of income poverty after social transfers (\%)

$\mathrm{X}_{3} \quad$ Severely materially deprived people (\%)

$\mathrm{X}_{4} \quad$ People living in households with very low work intensity $(\%)$
This indicator corresponds to the sum of persons who are: at risk of poverty after social transfers, severely materially deprived or living in households with very low work intensity. Persons are counted only once, even if they are affected by more than one of these phenomena.

People at risk-of-poverty are persons with an equivalized disposable income below the risk-of-poverty threshold, which is set at $60 \%$ of the national median equivalized disposable income (after social transfers).

The indicator measures the share of severely materially deprived persons who have living conditions severely constrained by a lack of resources. They experience at least 4 out of 9 following deprivations items: cannot afford (i) to pay rent or utility bills; (ii) keep home adequately warm; (iii) face unexpected expenses; (iv) eat meat, fish or a protein equivalent every second day; (v) a week holiday away from home; (vi) a car; (vii) a washing machine; (viii) a color TV; or (ix) a telephone.

The indicator is defined as the share of people aged 0-59 living in households with very low work intensity. These are households where on average the adults (aged 18-59, excluding students) work $20 \%$ or less of their total work potential during the past year. The indicator is part of the multidimensional poverty index.

The indicator measures the share of persons who are employed and have an equivalized disposable income below the risk-of-poverty threshold, which is set at $60 \%$ of the national median equivalized disposable income (after social transfers). For the purpose of this indicator, an individual is considered as being employed if he/she was employed for more than half of the reference year. The indicator is based on the EU-SILC (statistics on income, social inclusion and living conditions).

Population living in a dwelling with a leaking roof, damp walls, floors or foundation or rot in window frames of floor $(\%$ of population)

The indicator measures the share of the population experiencing at least one of the following basic deficits in their

housing condition: a leaking roof, damp walls, floors or foundation, or rot in window frames or floor. A breakdown by poverty status is available.

The indicator measures the share of the population aged 16 and over reporting unmet needs for medical care due to one of the following reasons: "Financial reasons", "Waiting list" and "Too far to travel" (all three categories are cumulated). Self-reported unmet needs concern a person's own assessment of whether he or she needed medical examination or treatment (dental care excluded), but did not have it or did not seek it. The data stem from the EU Statistics on Income and Living Conditions (EU SILC).

$X_{7} \quad$ Self-reported unmet need for medical examination and care $(\%$ of population aged 16 and over)

The indicator measures the share of total population having neither a bath, nor a shower, nor an indoor flushing toilet in their household.
$\mathrm{X}_{8} \quad$ Population having neither a bath, nor a shower, nor indoor flushing toilet in their household (\% of population)

in their household.


Table 2. Cont

No.$$
\text { Indicator }
$$

Population unable to keep home adequately warm (\% of population)

$\mathrm{X}_{10} \quad$ Overcrowding rate $(\%$ of population)

\section{Definition}

The indicator measures the share of population who are unable to keep their home adequately warm. Data for this indicator are being collected as part of the European Union Statistics on Income and Living Conditions (EU-SILC) to monitor the development of poverty and social inclusion in the EU. The data collection is based on a survey, which means that indicator values are self-reported.

The indicator measures the share of people living in overcrowded conditions in the EU. A person is considered to be living in an overcrowded household if the house does not have at least one room for the entire household as well as a room for a couple, for each single person above 18, for a pair of teenagers (12 to 17 years of age) of the same sex, for each teenager of different sex and for a pair of children (under 12 years of age). 
All the indicators listed in Table 2 represent destimulants, and thus slow down the accomplished development level of the phenomenon under analysis [32]. In this study, it means that the value increase of each indicator included in Table 2 stands for a decline in the level of sustainable development regarding the No Poverty area, which results in the ranking of a given country from the Visegrad Group as "worse" in terms of the analyzed criterion.

The gross domestic product at market prices in thousands of purchasing power standard per capita (GDP) was used to assess the level of socioeconomic development in the Visegrad Group countries. The statistical data necessary to carry out the research come from the Eurostat database [3]. The following methods were applied in empirical research: descriptive statistics, dynamics analysis, multidimensional statistical analysis with particular emphasis on linear ordering methods and regression analysis. The empirical analysis was carried out in accordance with the following stages of the research procedure:

1. Spatio-temporal comparative analysis of poverty indicators $\left(X_{1}-X_{10}\right)$ with the use of basic parameters of descriptive statistics and dynamics indexes.

2. Selection of final poverty indicators used to construct synthetic measures of sustainable development in the No Poverty area.

3. Normalization of final indicators using a fixed point of reference.

4. Construction of synthetic measures of sustainable development in the area of No Poverty and linear ordering of the Visegrad Group countries.

5. Analysis of the dynamics of changes in the values of synthetic measures of sustainable development in the No Poverty area for the analyzed countries.

6. Identification of correlations between the level of sustainable development in the No Poverty area and the level of socioeconomic development of the individual Visegrad Group countries using regression analysis.

It was adopted that the final poverty indicators used to construct synthetic measures of sustainable development can take the form of variables presenting the following properties [32]:

- Measurability;

- Completeness of statistical information in the analyzed period;

- Interpretability;

- Clearly defined method for influencing the sustainable development level in the area of No Poverty;

- Relatively high average spatio-temporal variation (average value CV $>10 \%$ );

- No excessive correlation of indicators (the parametric method of Hellwig's features classification was used to reduce the number of indicators). In accordance with Hellwig's method [33], first the poverty indicator most strongly correlated with all the analyzed indicators was selected. Next, to eliminate duplicating the information, poverty indicators significantly correlated with the indicator selected in the first stage were removed. The critical value of the correlation coefficient was determined using the following formula:

$$
r *=\operatorname{minmax}_{j}\left|r_{j k}\right|(j, k=1,2, \ldots, 10 ; j \neq k \text { number of poverty indicator }) .
$$

The first and the second stage were repeated until the last indicator was eliminated for each analyzed period. A detailed procedure algorithm is presented below [32]. The starting point was to establish a symmetric matrix of correlation coefficients between all poverty indicators covered by the research. 
1. In a symmetric matrix of correlation coefficients:

$$
\mathbf{R}\left[\begin{array}{cccc}
1 & r_{12} & \cdots & r_{110} \\
r_{21} & 1 & \cdots & r_{210} \\
\cdots & \cdots & \cdots & \cdots \\
r_{101} & r_{102} & \cdots & 1
\end{array}\right]
$$

the sum of the elements of each column is determined

$$
\mathbf{R}_{j}=\sum_{i=1}^{k}\left|r_{i j}\right|
$$

2. A column with s number is highlighted for which:

$$
\mathbf{R}_{s}=\max _{j}\left\{\mathbf{R}_{j}\right\}
$$

3. Elements $r_{i s}$, which satisfy the inequality, are selected from column $s$ :

$$
\left|r_{i s}\right| \geq r^{*}
$$

and the rows corresponding to these columns. The poverty indicator corresponding to the highlighted column is the first central indicator, and the indicators corresponding to the highlighted rows represent its satellite indicators.

4. The correlation matrix $\mathbf{R}$ is reduced by crossing out the highlighted columns and rows.

5. The steps listed in points 1-4 are repeated to determine the subsequent reduced matrices as well as central and satellite indicators. In this way, the isolated indicators can also be distinguished, i.e., not significantly correlated with any of the other distinguished indicators.

The presented procedure was also repeated for each period of the study, determining the separate sets of central and isolated indicators, from which the final indicators were selected. Ultimately, for the construction of the synthetic measure of sustainable development in the No Poverty area, to maintain its comparability in the analyzed period, the indicators most often considered central or isolated and characterized by the relatively high average variation were adopted as the final ones.

The normalization of final poverty indicators was the next stage of the research procedure. More information on the normalization of variables and the applied properties can be found, e.g., in the studies [34-38]. Since all the analyzed poverty indicators $\left(X_{1}-X_{10}\right)$ represent destimulants (an increase in the indicator value results in a decrease in the level of sustainable development), the unitarization formula taking the following form was used to normalize the final indicators [32,39]:

$$
z_{i j}^{t}=\frac{\max _{i} x_{i j}^{1}-x_{i j}^{t}}{\max _{i} x_{i j}^{1}-\min _{i} x_{i j}^{1}}
$$

where:

$z_{i j}^{t}$-normalized value of $j$-th indicator in $i$-th object-country in $t$-th period of the study;

$x_{i j}^{t}$-value of $j$-th indicator in $i$-th object-country in $t$-th period of the study;

$x_{i j}^{1}$-value of $j$-th indicator in $i$-th object-country in the first period of the study;

$i=1,2, \ldots n$-number of the object-country;

$j=1,2, \ldots f$-number of the final poverty indicator;

$t=1,2, \ldots, T$-number of the period of the study.

When normalizing the final values of poverty indicators, in successive time units, reference was made to their maximum and minimum values in the first period of the study 
(fixed point of reference). Such an approach allowed analyzing the dynamics of changes regarding the level of sustainable development in the area of No Poverty in the Visegrad Group countries against the beginning of the analyzed period. Normalized values of the final indicators represent stimulants of sustainable development.

The level of sustainable development was measured using the taxonomic measures of development, also referred to as synthetic measures. The method of average standardized sums was used as the function aggregating normalized values of the final diagnostic indicators:

$$
\operatorname{SSDNP}_{n}^{t}=\frac{1}{f} \sum_{j=1}^{f} z_{i j}^{t}
$$

$f$-number of final diagnostic indicators describing a given complex phenomenon; $i=1,2, \ldots, n$-number of the object-country;

$S S D N P_{n}^{t}$-synthetic measure of sustainable development in the No Poverty area defined for $n$-th object-country in $t$-th period of the study. More approaches to the construction, properties and applications of synthetic measures can be found in other studies [40-49].

To analyze the dynamics of change in the values of synthetic measures for sustainable development in the No Poverty area, chain absolute growths (absolute growth in the value of the synthetic measure compared to the previous period) and the average rate of changes in the synthetic measure value (average absolute growth in value in the last period of the study compared to the first period) were used.

The relationship between the level of socioeconomic development, measured by the level of GDP per capita and the level of sustainable development in the No Poverty area, was assessed on the basis of descriptive econometric models, constructed separately for the individual Visegrad Group countries. The heuristic method was used to identify the analytical form of econometric models. The best analytical form of the model, from the perspective of model fit to empirical data (maximum value of the coefficient of determination $\mathrm{R}^{2}$ ), was selected from the following functions: linear, polynomial, power, exponential and logarithmic one [50,51].

\section{Results}

3.1. Spatio-Temporal Comparative Analysis of Poverty Indicators in the Visegrad Group Countries in the Period 2005-2018

The indicator people at risk of poverty or social exclusion (\%) was the lowest in Czechia in all analyzed years, whereas the highest in Poland (2005-2010) and Hungary (2011-2018). A positive phenomenon was the decline in the indicator value in all analyzed countries. The highest drop of 26.4 percentage points was recorded in Poland. The differences between individual countries have also decreased, which was indicated by the declining value of the coefficient of variation and the difference between the maximum and minimum value.

The analysis of the value of people at risk of income poverty after social transfers indicator showed that, similarly to the previous indicator, the best situation in the entire period under study was observed in Czechia, while the worst one was in Poland. A positive phenomenon was the decrease in the indicator value recorded in all analyzed countries in 2018 compared to 2005. The highest drop of 5.7 percentage points was noted in Poland. The improving situation in all countries, as well as the decreasing variation, was demonstrated by the declining, year to year, value of the coefficient of variation and the difference between the maximum and minimum value.

Also, in the case of the severely materially deprived people indicator, the best situation in the entire analyzed period was recorded in Czechia. The indicator value in this country decreased from $11.8 \%$ in 2005 to $2.8 \%$ in 2018 . The worst situation in the period 20052008 was observed in Poland and in the subsequent years in Hungary. The maximum value decreased from $33.8 \%$ in 2005 to $10.1 \%$ in 2018 . A positive phenomenon was the fact that in each of the analyzed countries, the value of the indicator went down. However, attention should be paid to the differences between the individual countries. In the first four years, 
they can be described as small, whereas in the following years the value of the coefficient of variation ranged between $40 \%$ and $58 \%$.

The value of people living in households with very low work intensity indicator was the best, i.e., the lowest in the years 2005-2009, 2014 and 2017 in Slovakia; in 2010-2013, 2015 and 2018 in Czechia; and in 2016 in Poland. The worst situation was observed in Poland in 2005 and in Hungary in the subsequent years. In turn, a positive situation was reflected by a smaller variation between individual countries, which dropped from over $28 \%$ in 2005 to less than $9 \%$ in 2018. Another favorable phenomenon was the decreasing trend of the analyzed phenomenon in all countries. The biggest drop amounting to 8.7 percentage points was recorded in Poland, and the lowest one, i.e., 1.4 percentage points, was in Slovakia.

Czechia was also the leader regarding the value of the in work at-risk-of-poverty rate indicator. Its value presented the lowest level in this country. In turn, the worst situation in all analyzed years occurred in Poland. The exception was 2017, when the worst situation was recorded in Hungary, which was also the only country showing an upward trend in the value of this indicator. A positive phenomenon was manifested by the declining differences measured by the coefficient of variation.

Next, the indicator population living in a dwelling with a leaking roof, damp walls, floors or foundation or rot in window frames of floor by poverty status was analyzed. In this case, the best situation was recorded in Slovakia throughout the analyzed period, whereas the worst in Poland (2005-2007, 2009) and Hungary (2008, 2010-2018). A positive phenomenon was the decreasing trend in this indicator value in each country. On the other hand, large variations between the studied countries can be assessed as negative. The variation was above $50 \%$ for most of the analyzed period. The difference between the maximum and minimum value ranged between 11.0 and 36.7 percentage points.

Poland was the country in which the indicator self-reported unmet need for medical examination and care by sex reached the highest value in the entire period under study. The lowest value was recorded in Czechia. The discussed phenomenon was characterized by a downward trend in three analyzed countries. The exception was Slovakia, where an upward trend was observed. Attention should also be paid to a very high variation. The value of the coefficient of variation ranged between $62 \%$ and $94 \%$.

In the analyzed countries, a small part of the population had neither a bath, nor a shower, nor indoor flushing toilet in their household. The value of the indicator population having neither a bath, nor a shower, nor indoor flushing toilet in their household by poverty status ranged between $7 \%$ and $0.3 \%$. The countries presenting the highest value of this indicator were Poland (2005-2009) and Hungary (2010-2018). The lowest values were recorded in Czechia (2005-2007, 2010-2011, 2014-2018) and Slovakia (2008-2013). The observed changes were positive in all analyzed countries, as evidenced by the downward trend in all of them. However, extensive variations between individual countries should be emphasized at this point. The respective coefficient of variation ranged from $69 \%$ to $90 \%$.

Positive changes in all analyzed countries can be observed in the case of the population unable to keep home adequately warm by poverty status indicator. The trend showed a decreasing tendency for all countries. Czechia (2005-2006, 2008, 2014-2018) and Slovakia (2007-2014) were the countries in which this phenomenon presented the lowest level. The worst situations were in Poland (2005-2011) and Hungary (2012-2018). However, a positive phenomenon was the systematically decreasing variation between the individual countries.

The analysis of the overcrowding rate by poverty status indicator showed that the problem of household overcrowding, and thus the absence of adequate housing space, constituted an important phenomenon in the analyzed countries. The value of this indicator was relatively high. It adopted values between $15.7 \%$ and $54.1 \%$. The systematically decreasing value of this indicator in all analyzed countries is a positive phenomenon. Czechia recorded the best situation and Poland the worst in the analyzed period. The variations between individual countries were also reduced. 
The values of individual indicators recorded in the analyzed countries in the period under study are presented in the Figure 1 below.
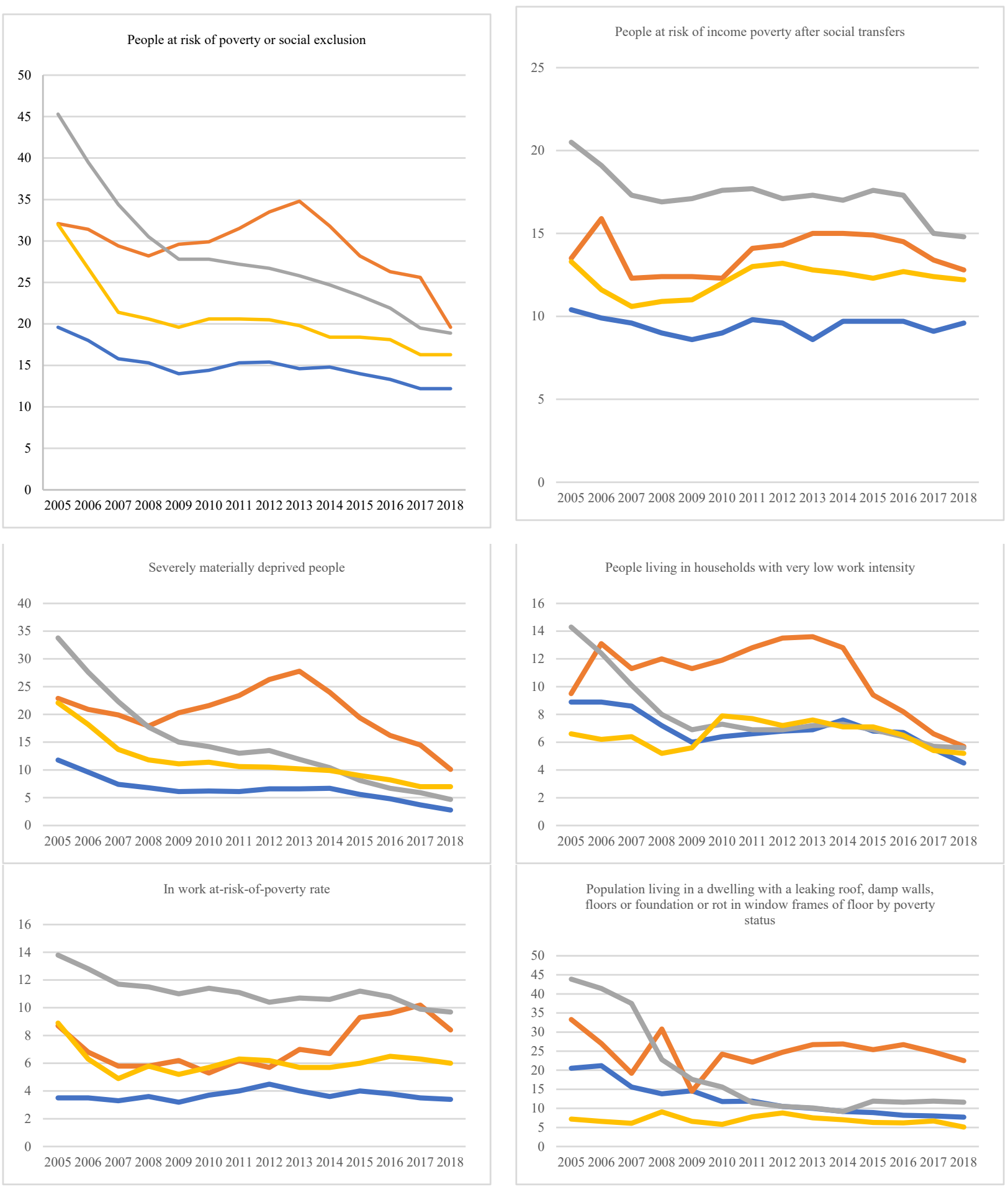

Figure 1. Cont. 


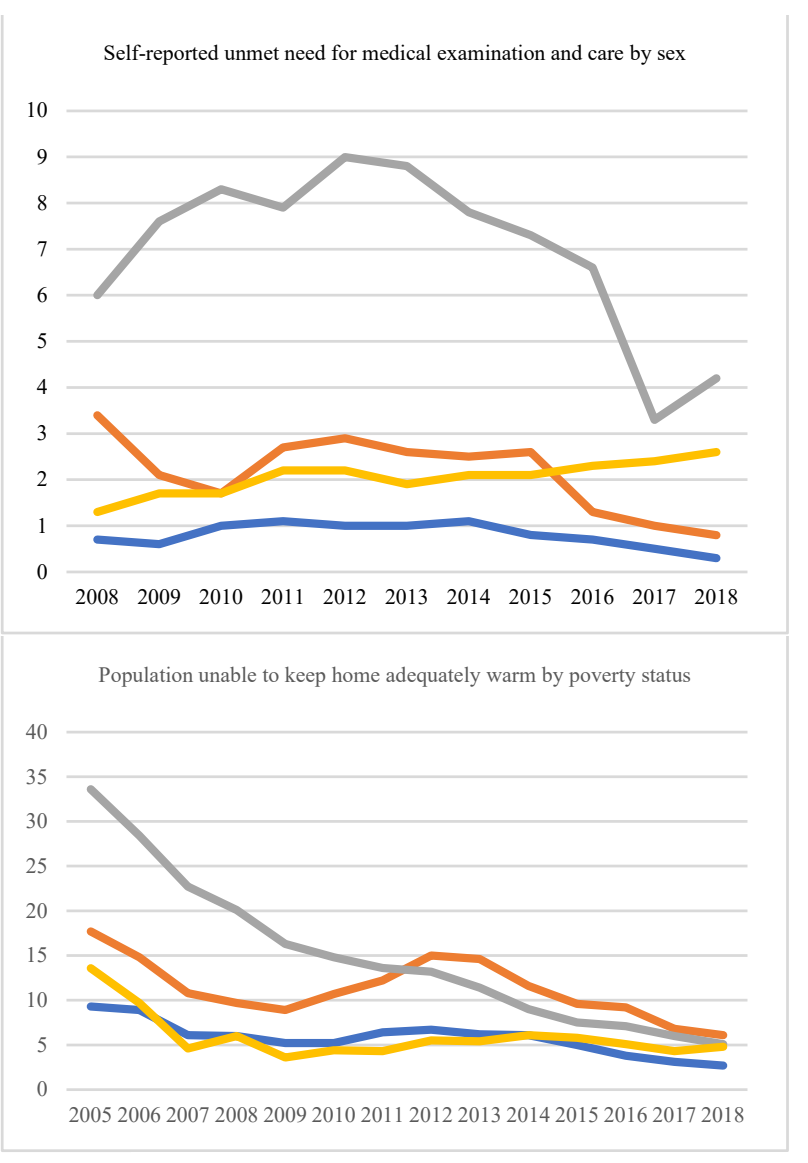

$\longrightarrow$ Czechia $\longrightarrow$ Hungary
Population having neither a bath, nor a shower, nor indoor flushing toilet in their household by poverty status

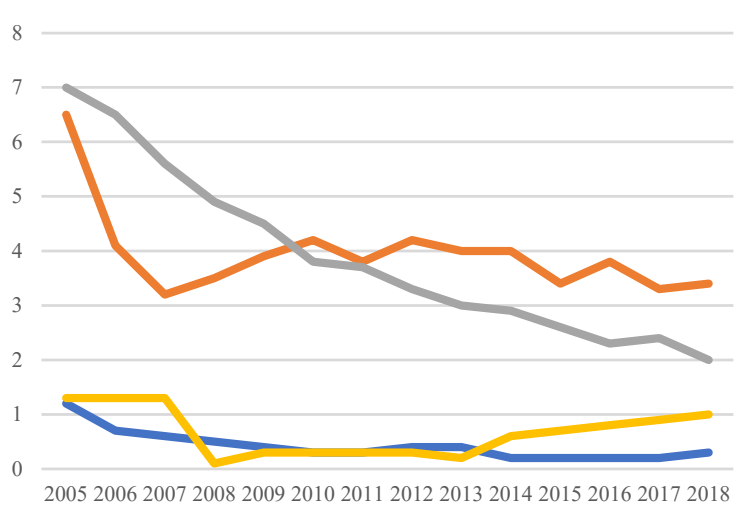

Overcrowding rate by poverty status

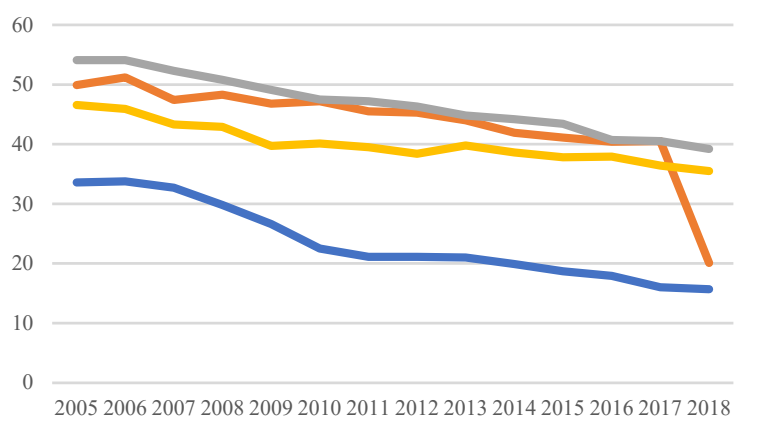

Poland Slovakia

Figure 1. The values of individual indicators in the analyzed period (\%). Source: authors' compilation based on Eurostat [3].

Looking at the individual countries covered by the analysis, it can be observed that Czechia was the evident leader among them. In the case of five indicators, Czechia took the most favorable position in all analyzed years. In total, Czechia was ranked as first 103 times. Slovakia was the leader 33 times and Poland only once. Hungary, in turn, was the country that never took the most favorable position. The worst situation was recorded in Poland and in Hungary. Poland came last 78 times, whereas Hungary came last 59 times.

\subsection{The Level of Sustainable Development in the No Poverty Area in the Visegrad Group Countries-Dynamic Presentation}

The sustainable development indicators in the No Poverty area presented in Table 2 were selected based on the required properties discussed in Section 2 of this study. The poverty indicators $X_{1}-X_{10}$ are measurable, interpretable, and of a destimulant nature. Statistical information for the $\mathrm{X}_{7}$-self-reported unmet need for medical examination and care (\% of population aged 16 and over) - indicator are not available for the years 2005-2007. Due to the substantive importance of this indicator for the assessment of the sustainable development level in the No Poverty area, it was decided that the final decision about narrowing down the scope of the research to 2008-2018 would be taken after analyzing variation and the reduction of baseline indicators using Hellwig's parametric method, in the $s$ when the $X_{7}$ indicator would be included in the set of final variables underlying the construction of synthetic measures for sustainable development in the No Poverty area.

Figure 2 shows the values of coefficients of variation for 10 poverty indicators in the VG countries in the years 2008-2018, and Figure 3 presents their average values. As can be seen, the greatest variations throughout the analyzed period were characteristic for two indicators, i.e., $X_{7}$ (\% of population aged 16 and over self-reported unmet need for 
medical examination) and $\mathrm{X}_{8}$ (\% of population having neither a bath, nor a shower, nor indoor flushing toilet in their household). The Visegrad Group countries presented the lowest average variation regarding the percentage of people at risk of income poverty after social transfers $\left(\mathrm{X}_{2}\right)$ and the percentage of people living in households with very low work intensity $\left(X_{4}\right)$.

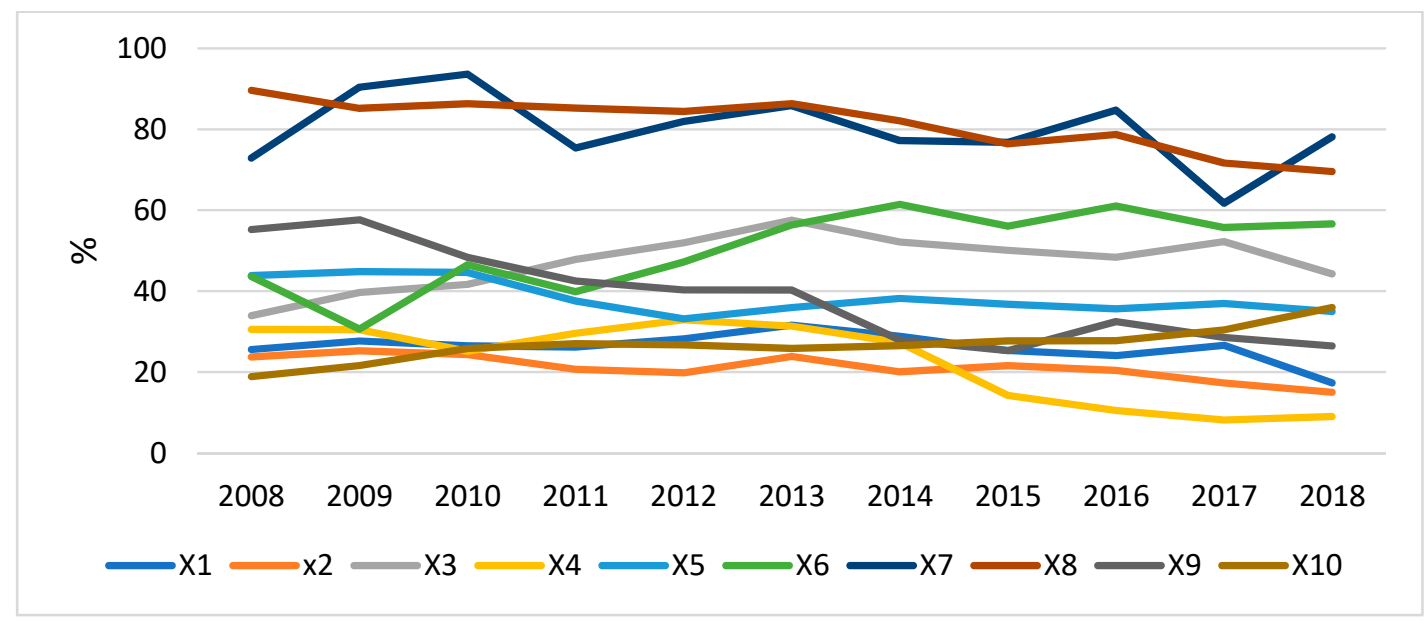

Figure 2. The values of coefficients of variation for the sustainable development indicators in the No Poverty area in the years 2008-2018 in the space of Visegrad Group countries. Source: authors' compilation based on Eurostat [3].

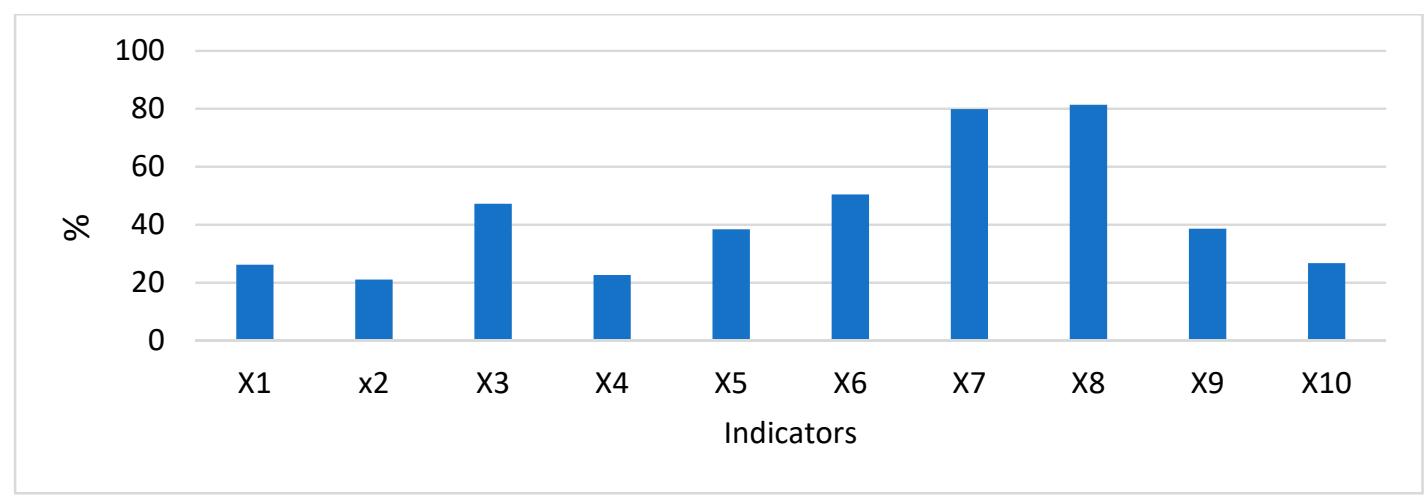

Figure 3. Average values of coefficients of variation for the sustainable development indicators in the No Poverty area in the years 2008-2018 in the space of Visegrad Group countries. Source: authors' compilation based on Eurostat [3].

Diagnostic indicators used for the construction of synthetic measures should remain uncorrelated to prevent duplicating similar information and, at the same time, represent other indicators not included in the construction of synthetic measures for sustainable development. Ultimately, the final set covered poverty indicators that were most frequently uncorrelated with the others. The average variation was also taken into account. The final poverty indicators are listed below (the frequency of their occurrence as uncorrelated with other indicators in 2008-2018 is presented in brackets):

$\mathrm{X}_{1}-\%$ of people at risk of poverty or social exclusion ( 8 times);

$\mathrm{X}_{6}$-\% of population living in a dwelling with a leaking roof, damp walls, floors or foundation or rot in window frames of floor (7 times);

$\mathrm{X}_{7}-\%$ of population aged 16 and over self-reported unmet need for medical examination and care (8 times);

$\mathrm{X}_{8}$ - \% of population having neither a bath, nor a shower, nor indoor flushing toilet in their household (5 times);

$\mathrm{X}_{10}$-overcrowding rate (\% of population) (6 times). 
The indicator $\mathrm{X}_{2}$-percentage of people at risk of income poverty after social transferwas repeated five times, however, it was not included in the final set due to the lowest average variation (21.1\%). The remaining poverty indicators, in the years 2008-2018, were repeated as uncorrelated with the remaining ones fewer times in the analyzed periods. The list of poverty indicators defined as central or isolated in individual years of the analyzed period is presented in Table 3.

Table 3. Poverty indicators distinguished as central or isolated in the analyzed period.

\begin{tabular}{|c|c|c|c|c|c|c|c|c|c|c|c|c|}
\hline$X_{i}$ & 2008 & 2009 & 2010 & 2011 & 2012 & 2013 & 2014 & 2015 & 2016 & 2017 & 2018 & Number "+" \\
\hline $\mathrm{X}_{1}$ & + & + & + & + & + & + & & + & + & & & 8 \\
\hline $\mathrm{X}_{2}$ & & + & + & & + & + & + & & & & & 5 \\
\hline$x_{3}$ & & & & & & & & + & & & + & 2 \\
\hline $\mathrm{X}_{4}$ & & & & + & + & & + & & & & + & 4 \\
\hline$X_{5}$ & + & & & & + & & & + & & & & 3 \\
\hline$X_{6}$ & + & + & + & + & & + & & & + & & + & 7 \\
\hline$X_{7}$ & + & & & + & & + & + & + & + & + & + & 8 \\
\hline $\mathrm{X}_{8}$ & & + & + & + & & + & + & & & & & 5 \\
\hline$X_{9}$ & & & & & + & & & & & + & & 2 \\
\hline$X_{10}$ & + & & + & + & + & + & & + & & & & 6 \\
\hline$r^{*}$ & 0.958 & 0.958 & 0.958 & 0.894 & 0.936 & 0.942 & 0.921 & 0.914 & 0.836 & 0.770 & 0.871 & $x$ \\
\hline
\end{tabular}

Where: + ,-respectively, the presence or absence of an indicator insignificantly correlated with the remaining ones (central or isolated) in accordance with Hellwig's method [32]. $r$ *-Formula (1). Source: authors' calculations based on Eurostat database.

Ultimately, the time scope of the conducted analyses addressing the level of sustainable development was limited to the years 2008-2018 due to the unavailability of previous statistical information for the final poverty indicator $X_{7}$.

The final poverty indicators were normalized (Formula 6), thus becoming the stimulants of sustainable development (no poverty indicators) and forming the basis for the construction of the synthetic measures of sustainable development in the No Poverty area presented in Figure 4.

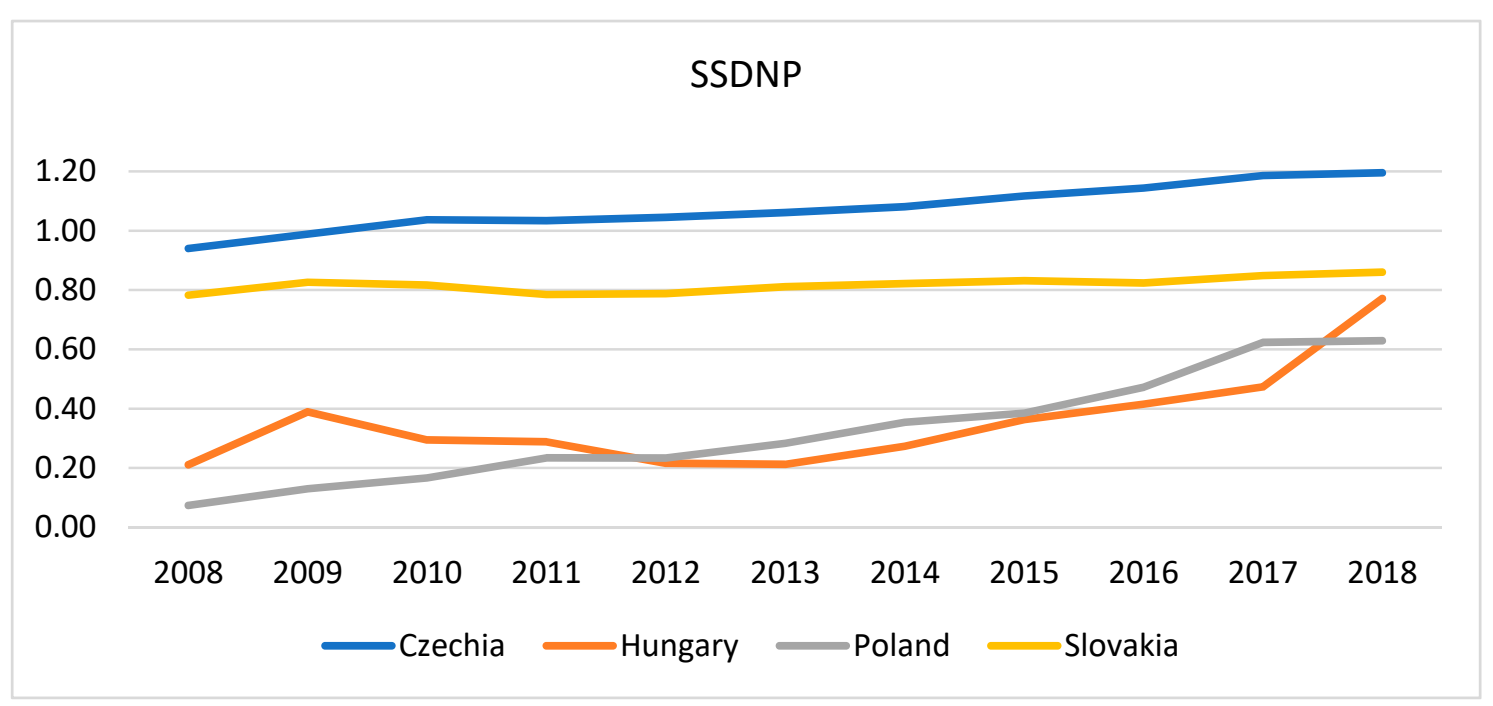

Figure 4. The values of synthetic measures of sustainable development (SSDNP) in the No Poverty area in the Visegrad Group countries. Source: authors' compilation based on Eurostat [3].

Table 4 and Figure 5 present the dynamics of change measures established for the synthetic measures of sustainable development in the No Poverty area. 
Table 4. Absolute growth values of the chain synthetic measures for sustainable development in the No Poverty area (SSDNP) for the Visegrad Group countries.

\begin{tabular}{ccccc}
\hline \multirow{2}{*}{ Years } & \multicolumn{4}{c}{ Absolute Changes } \\
\cline { 2 - 4 } & Czechia & Hungary & Poland & Slovakia \\
\hline $2009 / 2008$ & 0.0481 & 0.1785 & 0.0559 & 0.0432 \\
$2010 / 2009$ & 0.0487 & -0.0946 & 0.0364 & -0.0096 \\
$2011 / 2010$ & -0.0032 & -0.0066 & 0.0678 & -0.0316 \\
$2012 / 2011$ & 0.0112 & -0.0726 & -0.0005 & 0.0026 \\
$2013 / 2012$ & 0.0161 & -0.0035 & 0.0499 & 0.0233 \\
$2014 / 2013$ & 0.0198 & 0.0614 & 0.0704 & 0.0102 \\
$2015 / 2014$ & 0.0360 & 0.0900 & 0.0312 & 0.0099 \\
$2016 / 2015$ & 0.0271 & 0.0521 & 0.0871 & -0.0078 \\
$2017 / 2016$ & 0.0420 & 0.0579 & 0.1511 & 0.0254 \\
$2018 / 2017$ & 0.0090 & 0.2978 & 0.0057 & 0.0116 \\
\hline
\end{tabular}

Source: authors' compilation based on Eurostat [3].

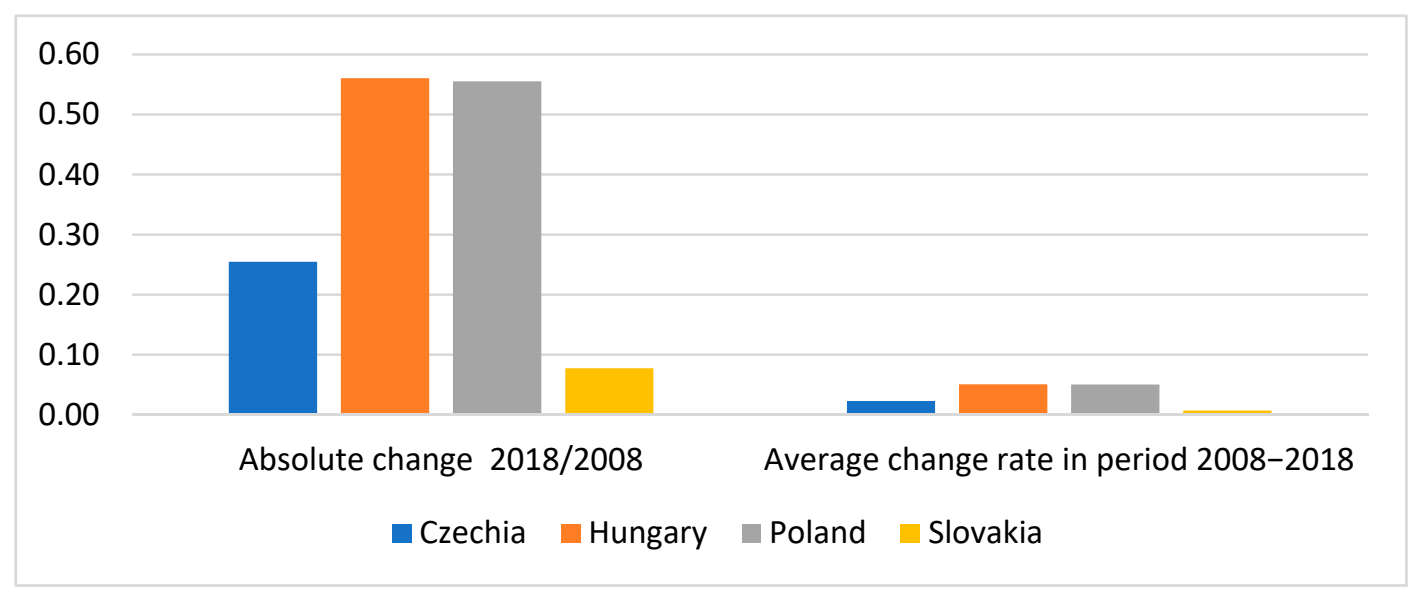

Figure 5. Absolute growth values and the average rate of change of the SSDNP indicator for the Visegrad Group countries. Source: authors' compilation based on Eurostat [3].

The next step of the conducted analysis was to identify correlations between the level of socioeconomic development in the individual countries of the Visegrad Group and the level of sustainable development in the No Poverty area. Figure 6 shows the variation of GDP per capita in the Visegrad Group countries covering the analyzed period.

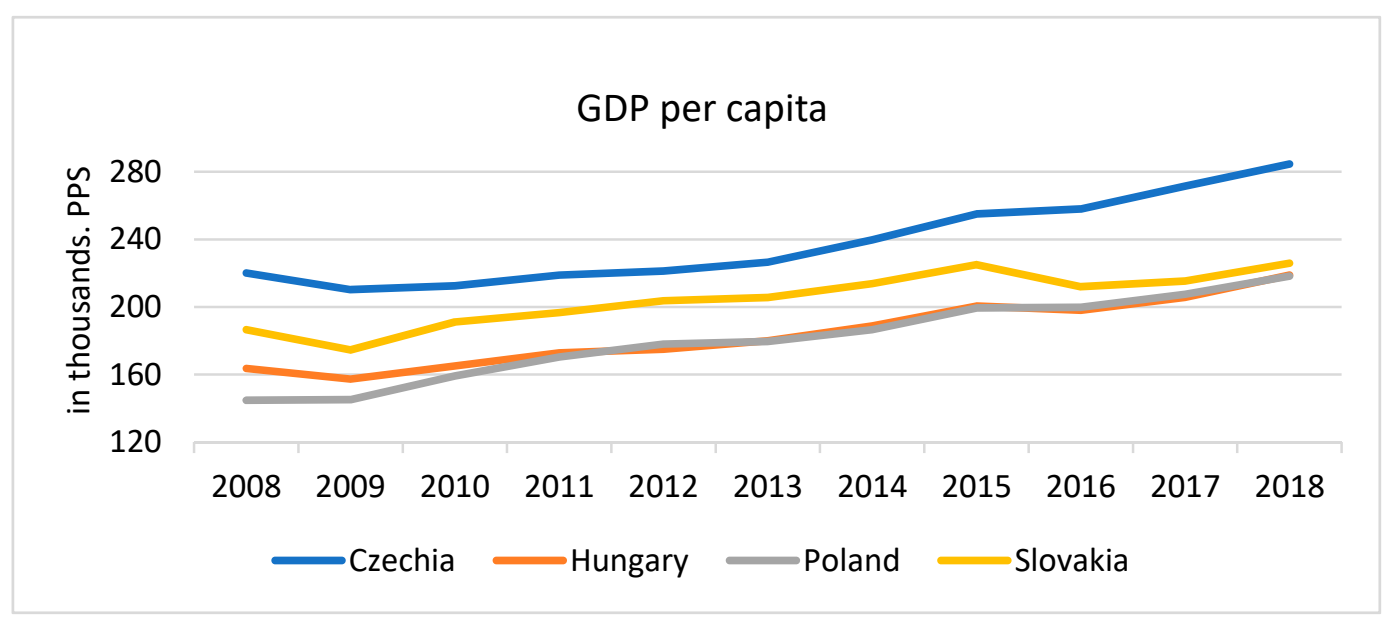

Figure 6. The level of GDP per capita in thousands PPS in the Visegrad Group countries in the years 2008-2018. Source: authors' compilation based on Eurostat [3]. 
Figure 7 presents correlations between the level of socioeconomic development (GDP per capita) and the level of sustainable development in the No Poverty area (SSDNP) in the Visegrad Group countries in the years 2008-2018.
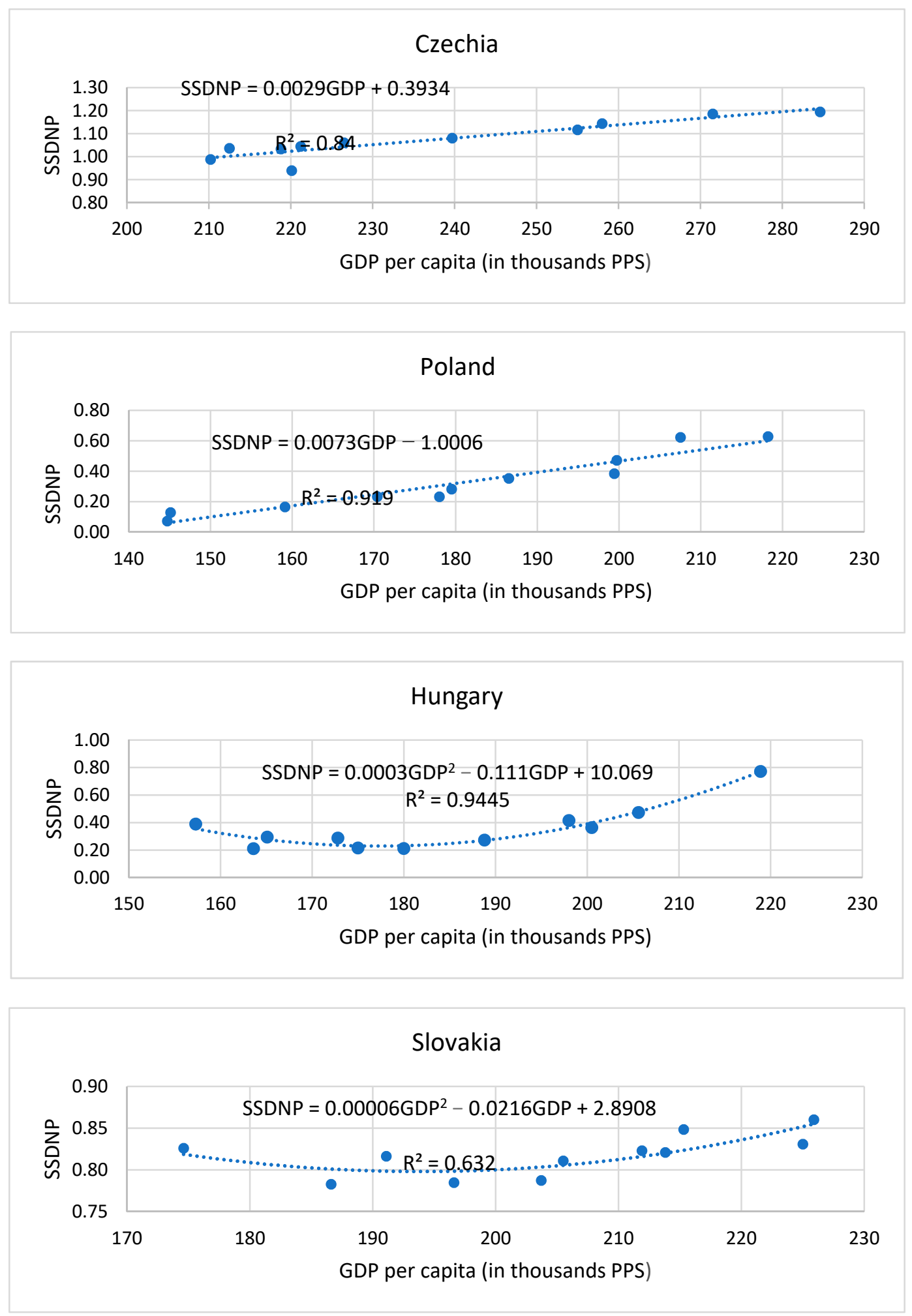

Figure 7. Correlations between GDP per capita and the level of sustainable development in the No Poverty in the Visegrad Group countries in the years 2008-2018. Source: authors' compilation based on Eurostat [3]. 
The degree of models' fit to empirical data was verified using the coefficient of determination $R^{2}$ and the significance of structural parameters. For the significance level $\alpha=0.05$ all structural parameters of the constructed models turned out to be significant $(p<0.05)$. In all countries of the Visegrad Group a significant correlation between the analyzed phenomena was observed.

\section{Discussion}

The conducted research shows that, in the years 2008-2018, the Visegrad Group countries differed significantly in terms of all aspects related to poverty adopted by the European Union for monitoring sustainable development in the No Poverty area (Table 2). However, the intensity of variation in the analyzed countries was different regarding the space of poverty indicators $\left(X_{1}-X_{10}\right)$, it was also changing over time (Figure 2). Definitely the greatest variation, but with a decreasing tendency, was observed in the case of population having neither a bath, nor a shower, nor indoor flushing toilet in their household $(\%)$-indicator $\mathrm{X}_{8}$ - and self-reported unmet need for medical examination and care $(\%$ of population aged 16 and over)-indicator $X_{7}$. The average values of the coefficient of variation in the years $2008-2018$ for these indicators were $81.40 \%$ and $79.88 \%$, respectively. However, in the case of the share of population having neither a bath, nor a shower, nor indoor flushing toilet in their household, the situation was definitely worse, although the improvement tendency was higher in Poland and Hungary than in Czechia and Slovakia. When it comes to the share of population aged 16 and over self-reported unmet need for medical examination and care, the situation in Poland was by far the worst and clearly different from other countries in the Visegrad Group. However, in the years 2017-2018, it improved considerably, which resulted in the significant reduction of disproportions between the analyzed countries. The coefficient of variation for $\mathrm{X}_{7}$ indicator in 2010 amounted to $93.63 \%$, whereas in 2018 it was $78.14 \%$, which, however, still reflects huge disproportions.

The Visegrad Group countries were characterized by the lowest average variation in terms of the share of people at risk of income poverty after social transfer $(\mathrm{CV}=21.10 \%)$ and the share of people living in households with very low work intensity $(\mathrm{CV}=22.65 \%)$. A noticeable trend for further reduction of the disproportions between the VG countries resulting from the above-mentioned indicators was also observed.

In the years 2008-2018, an increasing tendency was observed in the differences between the analyzed countries regarding the percentage of the population living in a dwelling with a leaking roof, damp walls, floors or foundation or rot in window frames of floor $\left(\mathrm{X}_{6}\right)$ and overcrowding rate $\left(\mathrm{X}_{10}\right)$. In the first case, it was caused by a significant deterioration of the situation in Hungary, in the second, by a much faster improvement in the value of $\mathrm{X}_{10}$ indicator in Czechia compared to other countries of the Visegrad Group.

A comprehensive assessment of the sustainable development variation in the area of poverty in the Visegrad Group countries requires both the level of development and the dynamics of its change to be analyzed. The level of sustainable development in the No Poverty area in the period 2008-2018 in the VG countries was diverse, but in each of the analyzed countries it showed an increasing tendency (Figure 4). Czechia turned out to be the evident leader in terms of poverty level elimination. Slovakia was ranked the second in the entire analyzed period. The remaining countries of the Visegrad Group achieved a much lower level of sustainable development in the area of poverty reduction, taking alternately the 3rd and 4th position. Hungary was listed at a more favorable third position in the years 2008-2011 and 2018, and Poland in 2012-2017.

The analysis of chain absolute growths calculated for synthetic measures of sustainable development in the No Poverty area (Table 4) showed that the annual uninterrupted absolute growth in the level of sustainable development was not recorded in the analyzed area in any of the studied countries. In each VG country, in the period 2008-2018, a decline in the level of sustainable development was observed in a given year compared to the previous year. Such a situation occurred in Czechia in 2011; in Poland in 2012; and in Slovakia in 2010, 2011 and 2016. In Hungary, the drop in the level of sustainable 
development in the area of poverty in relation to the previous year was recorded four times, i.e., in each year of the period 2010-2013.

By far the largest absolute growth in the level of sustainable development regarding the No Poverty area in 2018 compared to 2008 was observed in Hungary, a slightly lower one in Poland and definitely the lowest in Slovakia (Figure 5). A similar ranking of countries occurred regarding the average annual increase in the level of sustainable development in the area of poverty in the period 2008-2018. If similar dynamics of change in the level of development continue, an increase in the level of sustainable development can be expected in the coming years, along with the simultaneous leveling of the disproportions between the VG countries in the area of poverty.

It is noticeable that in the analyzed period, the ranking of the Visegrad Group countries in terms of sustainable development level in the No Poverty area as well as the socioeconomic development level measured by the level of GDP per capita were similar (Figures 4 and 6). Both phenomena also showed an increasing tendency for change. In all countries, in the years under study, the significant correlations between the level of GDP per capita and the level of sustainable development in the No Poverty area were recorded (Figure 7). In Czechia and Poland, the correlation between GDP per capita and the level of sustainable development in the No Poverty area was of linear nature, which means that the increase in the level of sustainable development in the No Poverty area, in the analyzed period, turned out to be proportional to the increase in the level of GDP per capita. In Hungary and Slovakia, this correlation remained of nonlinear nature and was best reflected by the square function. In the VG countries, the level of GDP per capita remains one of the key factors in fighting poverty. In Hungary and Poland, more than $90 \%$ of the variation related to the level of sustainable development in the No Poverty area was explained by the level of GDP per capita. The weakest correlation occurred in Slovakia, which implies that despite the growing tendency for both phenomena, the secondary distribution of society's income carried out through the state budget does not ensure the level of support for the poorest in the form of social aid or benefits contributing extensively to the elimination of poverty. It is worth noting that Slovakia experienced, by far, the lowest average annual increase in the level of sustainable development in the No Poverty area during the period under study. The best situation in this respect was recorded in Hungary and Poland.

\section{Conclusions}

The identified correlation between the reduction of poverty in individual Visegrad Group countries and the level of GDP per capita may only seemingly be obvious. For many years, the source literature has been addressing the impact of economic growth on the reduction of unemployment [52-56]. The literature also attempts to define and measure pro-poor growth $[57,58]$. Moreover, the empirical research carried out worldwide does not provide a clear answer to the question of whether economic growth favors the poor [59-61]. Therefore, for the Visegrad Group countries, despite the strong impact of GDP per capita level on poverty reduction in the analyzed period, it is recommended to finance programs supporting the poor and implement the policy ensuring the participation of social groups presenting different levels of wealth in the creation and distribution of GDP. Continuous monitoring of poverty indicators in the context of sustainable development is absolutely essential in preparing development strategies, as well as the social and economic policy goals of the Visegrad Group countries.

The V4 countries are very often approached as a homogeneous area where the same problems can be observed. These countries also try to conduct a common external policy towards, for example, other EU countries. Despite that, considerable differences can be observed while analyzing the situation in individual countries. These differences are also visible in relation to the analyzed area and when taking into account the values of individual indicators. Each of these countries has also implemented its own monitored sustainable development strategies. A respective example is the Strategy for Responsible Development (SRD) implemented in Poland. It is an overarching strategy, being the Polish 
response to the goals set out in the 2030 Agenda. The model of development for Poland included in the strategy is consistent with the vision of the world set out in the agenda by the United Nations. The Sustainable Development Goals reporting platform, provided by the Statistics Poland, is used to monitor the sustainable development goals and report data for the global needs [62].

The general conclusion formulated regarding the analyzed countries is that the situation in the studied area is improving significantly. Despite that, certain differences can be observed between the individual countries in relation to some indicators. It should, however, be emphasized that these differences are systematically decreasing. The largest occurred in the first analyzed years. These were also the first years after the discussed countries joined the European Union. In addition, they experienced their socioeconomic system changes. The individual countries approached the transformation processes differently. Moreover, Czechoslovakia broke up into two independent states, the Czech Republic and Slovakia. It was Slovakia, the smallest country created, in a way, "from scratch", which faced the largest economic and social problems.

Sirovátka and Mareš emphasized that the poverty index in the Czech Republic is one of the lowest in Europe. The authors have described that the practice in the scope of social policy is effective, but it may appear not to be sustainable in a long term perspective. Other researchers have indicated that the Czech Republic is a sustainable country in terms of disposable incomes of households. Poverty is also an important problem in Slovakia, especially in the eastern and southern parts of the country. The areas that are affected by poverty to the highest degree are characterized by a relatively high share of children and young people in the population [63-65].

Further empirical research could cover all countries and regions of the European Union and attempt to assess the spatio-temporal variation of the sustainable development level in the area of poverty and the correlations between the level of socioeconomic development and progress in counteracting poverty.

The improvement of the currently used indicators and the identification of the new ones to be applied in measuring and monitoring progress in the area of poverty elimination remains the challenge for the official statistics of the European Union.

The following conclusions result from the conducted empirical research:

1. The Visegrad Group countries show significant, however decreasing, differences in terms of the indicators describing poverty in the context of sustainable development (the exceptions are the share of population living in a dwelling with a leaking roof, damp walls, floors or foundation or rot in window frames of floor and the overcrowding rate).

2. The VG countries were characterized by the highest average dispersion related to the population having neither a bath, nor a shower, nor indoor flushing toilet in their household (in \%) and the lowest related to the percentage of people at risk of income poverty after social transfer.

3. In the VG countries, an ongoing increase in the level of sustainable development in the No Poverty area was recorded. Czechia was characterized by the highest level of sustainable development, followed by Slovakia. However, the highest average dynamics of change occurred in Poland and in Hungary, which resulted in the elimination of disproportions in this respect.

4. The level of GDP per capita significantly discriminated the level of sustainable development in the No Poverty area in all VG countries. The strongest correlation was observed in Hungary and the weakest in Slovakia.

In the context of recommendations related to an effective implementation of the concept of sustainable development in the V4 countries in the coming years, the problem of population aging should be emphasized at the very beginning. The described phenomenon is a sign of our times-we live longer, while the fertility rate persists at a low level. In this respect it may be recommended to initiate more extensive activities focused on the intensification of pro-family policy and the allocation of child benefits which, to some 
extent, has already been implemented in the analyzed countries. In addition, promoting a large family model, supported by the system of discounts and promotions on the part of public and private sector entities may turn out an effective solution. Senior citizens should also be provided with more care. Special programs supporting and activating seniors should be implemented. They need be covered with appropriate medical care. Moreover, it is more difficult to talk about sustainable development when a certain part of the society is at risk of poverty. A narrow group of rich people is not the evidence of wealth and stability, but a broad and strong middle class. It should be noted that despite the undeniable socioeconomic development of the $\mathrm{V} 4$ countries, the scale of stratification requires improvement. Better quality of life in big cities does not always coincide with the improvement of living conditions in the provincial areas where, in total, the majority of the V4 countries' population resides. Moreover, the stratification itself carries a number of consequences, including the phenomenon of social exclusion, poverty, addictions, crime, inheriting unemployment and low social activity. It is recommended to implement comprehensive programs co-financed from public funds aimed at equalizing development opportunities (e.g., educational) and reducing the extent poverty (e.g., social support) [6].

Author Contributions: All authors designed the research and analyzed the data. All authors have read and agreed to the published version of the manuscript.

Funding: The project was financed by the Ministry of Science and Higher Education in Poland under the program "Regional Initiative of Excellence" 2019-2022 project number 015/RID/2018/19 total funding amount 10721 040,00 PLN.

Conflicts of Interest: The authors declare no conflict of interest.

\section{References}

1. Ministry of Science and Higher Education. Available online: https://www.gov.pl/web/nauka/grupa-wyszehradzka-visegradgroup (accessed on 11 November 2020).

2. Visegrad Group. Available online: http://www.visegradgroup.eu/v4-110412-1 (accessed on 11 November 2020).

3. Eurostat Database. Available online: https://ec.europa.eu/eurostat/data/database (accessed on 11 November 2020).

4. Raszkowski, A.; Bartniczak, B. Towards Sustainable Regional Development: Economy, Society, Environment, Good Governance Based on the Example of Polish Regions. Transform. Bus. Econ. 2018, 17, 225-245.

5. Raszkowski, A.; Bartniczak, B. On the Road to Sustainability: Implementation of the 2030 Agenda Sustainable Development Goals (SDG) in Poland. Sustainability 2019, 11, 366. [CrossRef]

6. Raszkowski, A.; Bartniczak, B. Sustainable Development in the Central and Eastern European Countries (CEECs): Challenges and Opportunities. Sustainability 2019, 11, 1180. [CrossRef]

7. Fiedor, B. (Ed.) Podstawy Ekonomii Środowiska i Zasobów Naturalnych; C.H. Beck: Warszawa, Poland, 2002; ISBN 83-7110-868-0.

8. Pawłowski, A. How many dimensions does sustainable development have? Sustain. Dev. 2008, 16, 81-90. [CrossRef]

9. Pawłowski, A. Sustainable Development as a Civilizational Revolution: A Multidisciplinary Approach to the Challenges of the 21st Century; CRC Press: London, UK, 2011; ISBN 978-0415578608.

10. Heberle, L. Sustainable Urban Development: Local Strategies and Global Solutions. In Local Sustainable Urban Development in a Globalized World. Urban Planning and Environment; Heberle, L., Opp, S., Eds.; Ashgate Publishing: Farnham, UK, 2008; pp. 1-8. ISBN 978-0754649946.

11. Connelly, A.; Carter, J.; Handley, J.F.; Hincks, S. Enhancing the practical utility of risk assessments in climate change adaptation. Sustainability 2018, 10, 1399. [CrossRef]

12. Kelly, P.M.; Adger, W.N. Theory and practice in assessing vulnerability to climate change and facilitating adaptation. Clim. Chang. 2000, 47, 325-352. [CrossRef]

13. Palmer, J. Environmental Education in the 21st Century: Theory, Practice, Progress and Promise; Routledge: New York, NY, USA, 1998; ISBN 978-0415131971.

14. Bartniczak, B.; Raszkowski, A. Sustainable Development in African Countries: An Indicator-Based Approach and Recommendations for the Future. Sustainability 2019, 11, 22. [CrossRef]

15. Bartniczak, B.; Raszkowski, A. Sustainable development in Asian countries-Indicator-based approach. Probl. Ekorozw. Probl. Sustain. Dev. 2019, 14, 29-42.

16. Bartniczak, B.; Raszkowski, A. Sustainable development in the Russian Federation-Indicator-based approach. Probl. Ekorozw. Probl. Sustain. Dev. 2017, 12, 133-142.

17. Archer, M. Education for Sustainable Development. In Children and Sustainable Development: Ecological Education in a Globalized World; Battro, A., Léna, P., Sorondo, M., Braun, J., Eds.; Springer International Publishing: Cham, Germany, 2017 ; pp. 103-125. ISBN 978-3319471297. 
18. Bartniczak, B.; Raszkowski, A. Sustainable forest management in Poland. Manag. Environ. Qual. Int. J. $2018,29,666-677$. [CrossRef]

19. Sobczak, E.; Bartniczak, B.; Raszkowski, A. Aging Society and the Selected Aspects of Environmental Threats: Evidence from Poland. Sustainability 2020, 12, 4648. [CrossRef]

20. Przybyła, K.; Kachniarz, M.; Hełdak, M. The Impact of Administrative Reform on Labour Market Transformations in Large Polish Cities. Sustainability 2018, 10, 2860. [CrossRef]

21. Report of the World Commission on Environment and Development: Our Common Future. UN Documents, Gathering a Body of Global Agreements. 1987. Available online: http:/ / www.un-documents.net/wced-ocf.htm (accessed on 12 November 2020).

22. Agenda 21. United Nations Conference on Environment \& Development Rio de Janerio, Brazil. United Nations Sustainable Development, 1992. Available online: https://sustainabledevelopment.un.org/content/documents/Agenda21.pdf (accessed on 12 November 2020).

23. United Nations. Millennium Development Goals (MDGs). Available online: http://www.un.org/millenniumgoals/ (accessed on 12 November 2020).

24. Millennium Development Goals Indicators. The Official United Nations Site for the MDG Indicators. Available online: http: //mdgs.un.org/unsd/mdg/Host.aspx?Content=Indicators/OfficialList.htm (accessed on 12 November 2020).

25. United Nations. The Future We Want. Outcome Document of the United Nations Conference on Sustainable Development, Rio de Janeiro, Brazil. 2012. Available online: https://sustainabledevelopment.un.org/content/documents/733FutureWeWant.pdf (accessed on 12 November 2020).

26. United Nations. Transforming Our World: The 2030 Agenda for Sustainable Development. Available online: https:// sustainabledevelopment.un.org/post2015/transformingourworld (accessed on 12 November 2020).

27. United Nations Statistics Division. Global SDG Indicators Database. Available online: https://unstats.un.org/sdgs/indicators/ database/ (accessed on 12 November 2020).

28. Sustainable Development Goals. Available online: https: / / sustainabledevelopment.un.org/ ?menu=1300 (accessed on 12 November 2020).

29. United Nations. The Sustainable Development Goals Report 2018. Available online: https://unstats.un.org/sdgs/files/report/ 2018/TheSustainableDevelopmentGoalsReport2018-EN.pdf (accessed on 12 November 2020).

30. Publications Office of the European Union. Sustainable Development in the European Union, Overview of Progress towards the SDGs in an EU Context, 2017 Edition. Available online: https:/ / ec.europa.eu/eurostat/documents/3217494/8461633/KS-04-17780-EN-N.pdf (accessed on 12 November 2020).

31. United Nations. Take Action for the Sustainable Development Goals. Available online: https://www.un.org/sustainabledevelopment/ sustainable-development-goals/ (accessed on 12 November 2020).

32. Zeliaś, A. (Ed.) Taksonomiczna Analiza Przestrzennego Zróżnicowania Poziomu życia w Polsce w Ujęciu Dynamicznym; Wyd. UE w Krakowie: Kraków, Poland, 2000.

33. Hellwig, Z. Wielowymiarowa analiza porównawcza i jej zastosowanie w badaniach wielocechowych obiektów gospodarczych. In Metody i Modele Matematyczno-Ekonomiczne w Doskonaleniu Zarzadzania Gospodarka Socjalistyczna; Welfe, A., Ed.; PWE: Warszawa, Poland, 1981.

34. Kukuła, K. Metoda Unitaryzacji Zerowanej; Wydawnictwo Naukowe PWN: Warszawa, Poland, 2000; ISBN 8301130970.

35. Walesiak, M. Uogólniona miara Odległości w Statystycznej Analizie Wielowymiarowej; Wydawnictwo Akademii Ekonomicznej: Wrocław, Poland, 2006; ISBN 8370118186.

36. Jajuga, K.; Walesiak, M. Standardisation of data set under different measurement scales. In Classification and Information Processing at the Turn of the Millennium; Decker, R., Gaul, W., Eds.; Springer: Berlin/ Heidelberg, Germany, 2000; pp. 105-112. ISBN 978-3540675891.

37. Zeliaś, A. Some Notes on the Selection of Normalisation of Diagnostic Variables. Stat. Transit. 2002, 5, 787-802.

38. Sobczak, E. Segmentacja Rynków Zagranicznych; Wydawnictwo Uniwersytetu Ekonomicznego we Wrocławiu: Wrocław, Poland, 2010.

39. Strahl, D.; Walesiak, M. Normalizacja zmiennych w skali przedziałowej i ilorazowej w referencyjnym systemie granicznym. Przegląd Stat. 1997, 1, 69-77.

40. Bartosiewicz, S. Propozycja metody tworzenia zmiennych syntetycznych. Pr. Nauk. AE Wrocławiu 1976, 84, 5-7.

41. Borys, T. Kategoria Jakości w Statystycznej Analizie Porównawczej; Research Papers of Wrocław University of Economics 1984, No. 284; Series: Monographs and Studies, No. 23; Wrocław University of Economics: Wrocław, Poland, 1984.

42. Cieślak, M. Taksonomiczna procedura programowania rozwoju gospodarczego i określenia zapotrzebowania na kadry kwalifikowane. Przeglad Stat. 1974, 21, 29-39.

43. Dittman, P.; Pisz, Z. Metoda dynamicznego badania zróżnicowania przestrzennego zjawisk społeczno-ekonomicznych. Wiadomości Stat. 1975, 11, 27-28.

44. Dmytrów, K. Comparison of Several Linear Ordering Methods for Selection of Locations in Order picking by Means of the Simulation Methods. Acta Univ. Lodz. Folia Oeconomica 2018, 5, 81-96. [CrossRef]

45. Grabiński, T.; Wydymus, S.; Zeliaś, A. Metody Taksonomii Numerycznej w Modelowaniu Zjawisk Społeczno-Gospodarczych; PWE: Warszawa, Poland, 1989.

46. Hellwig, Z. Zastosowanie metody taksonomicznej do typologicznego podziału krajów ze względu na poziom ich rozwoju oraz zasoby i strukturę wykwalifikowanych kadr. Przeglą Stat. 1968, 4, 307-327. 
47. Młodak, A. Hierarchiczność a porządkowanie obiektów w statystyce regionalnej. Wiadomości Stat. 2009, 4, 11-25.

48. Nowak, E. Badanie zgodności metod konstruowania taksonomicznych mierników rozwoju. Przegląd Stat. 1982, $29,455-463$.

49. Strahl, D. Propozycja konstrukcji miary syntetycznej. Przeglad Stat. 1978, 25, 205-215.

50. Maddala, G. Ekonometria; Wydawnictwo naukowe PWN: Warszawa, Poland, 2006.

51. Greene, W. Econometric Analysis; Pearson Education International: Upper Saddle River, NJ, USA, 2003.

52. Panek, T. Wzrost sprzyjający ubogim: Koncepcja i pomiar dla Polski w latach 2005-2015. ISiD Work. Pap. 2018, 50, 106.

53. Kakwani, N.; Pernia, E. What is pro-poor growth? Asian Dev. Rev. 2000, 18, 1-16.

54. Kakwani, N.; Khandker, S.; Son, H. Pro-Poor Growth: Concepts and Measurement with Country Case Studies; International Poverty Centre Working Paper 2004, No. 1; UNDP_International Poverty Centre: Brasilia, Brazil, 2004.

55. Araar, A.; Duclos, J.-Y.; Audet, M.; Makdissi, P. Testing for pro-poorness of growth, with an application to Mexico. Rev. Income Wealth 2009, 55, 853-881. [CrossRef]

56. Bibi, S.; Duclos, J.-Y.; Verdier-Chouchane, A. Assessing absolute and relative pro-poor growth, with an application to selected African countries. Econ. Open-Access Open-Assess. E-J. 2012, 6, 1-43. [CrossRef]

57. Ravallion, M.; Chen, S. Measuring pro-poor growth. Econ. Lett. 2003, 78, 93-99. [CrossRef]

58. Kraay, A. When is growth pro-poor? Evidence from a panel of countries. J. Dev. Econ. 2006, 80, 198-227. [CrossRef]

59. Lopez, H. Did Growth Become Less Pro-Poor in the 1990s? World Bank Policy Research Working Paper; World Bank: Washington, DC, USA, 2006; p. 3931.

60. Ashley, R. Growth may be good for the poor, but decline is disastrous: On the non-robustness of the Dollar -Kraay Result. Int. Rev. Econ. Financ. 2007, 17, 333-338. [CrossRef]

61. Harmáček, J.; Syrovátka, M.; Dušková, L. Pro-poor growth in East Africa. Q. Rev. Econ. Financ. 2017, 64, 82-93. [CrossRef]

62. Sustainable Development Indicators for Poland. Available online: https://stat.gov.pl/cps/rde/xbcr/gus/as_Sustainable_ Development_Indicators_for_Poland.pdf (accessed on 30 December 2020).

63. Syrovátka, T.; Mareš, P. Poverty, social exclusion and social policy in the Czech Republic. Soc. Policy Adm. 2006, 40, 288-303. [CrossRef]

64. Janský, P.; Kalíšková, K.; Münich, D. Does the Czech Tax and Benefit System Contribute to One of Europe's Lowest Levels of Relative Income Poverty and Inequality? East. Eur. Econ. 2016, 54, 191-207. [CrossRef]

65. Piwowar, A.; Dzikuć, M. Poverty and Social Exclusion: Is this a Problem in Rural Areas in the Visegrad Group Countries. Eur. Res. Stud. J. 2020, XXIII, 45-54. [CrossRef] 